\title{
Rat adipose tissue rapidly accumulates and slowly releases an orally-administered high vitamin D dose
}

\author{
D. A. Janneke Brouwer*, Jackelien van Beek, Harri Ferwerda, Astrid M. Brugman, \\ Fiona R. M. van der Klis, H. Jacoline van der Heiden and Frits A. J. Muskiet \\ Central Laboratory for Clinical Chemistry, University Hospital Groningen, PO Box 30.001, 97 RB Groningen, \\ The Netherlands
}

(Received 29 May 1997-Revised 11 December 1997-Accepted 22 December 1997)

\begin{abstract}
We investigated the effect of oral high-dose cholecalciferol on plasma and adipose tissue cholecalciferol and its subsequent release, and on plasma 25-hydroxyvitamin D (25(OH)D). Female Wistar rats (n 126) received $37.5 \mu \mathrm{g}$ cholecalciferol/d for $14 \mathrm{~d}$ and were subsequently studied for a further $88 \mathrm{~d}$. Two subgroups of eighteen rats each were fasted for $3 \mathrm{~d}$ immediately after treatment (days 14-17) and at the end of the study (days 98-101). During treatment, plasma cholecalciferol increased rapidly to reach a steady-state. Plasma 25(OH)D and adipose tissue cholecalciferol increased linearly for $1-2 \mathrm{~d}$ after treatment. Serum $\mathrm{Ca}$ and inorganic phosphate also increased. Subsequently half-lives of plasma cholecalciferol and $25(\mathrm{OH}) \mathrm{D}$, and perirenal and subcutaneous adipose tissue were: 1.4, 22.5, 97.5 and $80.9 \mathrm{~d}$ respectively. Fasting, as compared with ad libitum feeding, caused increased plasma free fatty acids, weight loss up to $14 \%$ and increased adipose tissue cholecalciferol ( $\mathrm{nmol} / \mathrm{g}$ wet weight). It did not affect plasma cholecalciferol immediately after cholecalciferol treatment, but raised plasma $25(\mathrm{OH}) \mathrm{D}$. Fasting at the end of the study decreased plasma cholecalciferol and increased plasma $25(\mathrm{OH}) \mathrm{D}$. We conclude that orally-administered cholecalciferol rapidly accumulates in adipose tissue and that it is very slowly released while there is energy balance. Fasting causes preferential loss of triacylglycerols from adipose tissue, as opposed to cholecalciferol, but nevertheless augments plasma $25(\mathrm{OH}) \mathrm{D}$. Adipose tissue may act as a 'buffer to functional vitamin D status' by preventing, to a certain extent, unregulated production of $25(\mathrm{OH}) \mathrm{D}$ from dietary vitamin $\mathrm{D}$, and by slowly releasing vitamin $\mathrm{D}$ under fasting conditions.
\end{abstract}

Cholecalciferol: Plasma 25-hydroxyvitamin D: Calcium: Blood

Adequate vitamin D status is essential for the prevention of rickets in children, and osteomalacia (Fraser, 1980) and probably osteoporosis (Compston, 1995) in adults. Based on, for example, the wide organ distribution of the vitamin $D$ receptor, it is becoming increasingly clear that vitamin $\mathrm{D}$ metabolites are not only important in (bone) Ca homeostasis, but also for adequate functioning of many other systems (Reichel et al. 1989).

Present vitamin D supplementation recommendations concern post-menopausal women (Dawson-Hughes et al. 1991; Compston, 1995) and the elderly over 75 years (The Committee on Nutrition of the Elderly, Food and Nutrition Council, 1995) who live at high latitudes. These groups are recommended to take vitamin $\mathrm{D}$ supplements during winter. The daily dosage is, however, subject to discussion, because of remaining concern about (cumulative) toxicity (Schwartzman \& Franck, 1987).
Plasma 25-hydroxyvitamin D (25(OH)D) level is widely regarded as the most reliable index of vitamin $D$ status. However, oral supplementation of adults with either 10 or $20 \mu \mathrm{g}$ cholecalciferol/d does not cause much difference in plasma 25(OH)D concentrations (Lips et al. 1988; van der Klis et al. 1996). On the basis of these results, it was suggested that adipose tissue functions as a vitamin Dbuffering system that to a certain extent prevents uncontrolled synthesis of $25(\mathrm{OH}) \mathrm{D}$ in the liver (van der Klis et al. 1996). Mawer et al. (1972) had suggested previously that storage in tissue lipid may limit potential vitamin D toxicity, while Rosenstreich et al. (1971) suggested that slow release of vitamin $D$ from adipose tissue may be an important factor in long-term vitamin D status.

We investigated the effect of daily oral administration of high-dose $(37.5 \mu \mathrm{g})$ cholecalciferol to rats on cholecalcif-

Abbreviations: 25(OH)D, 25-hydroxyvitamin D.

*Corresponding author: Dr D. A. J. Brouwer, fax +31 050361 2290, email d.a.j.brouwer@lab.azg.nl 
erol accumulation in adipose tissue and its subsequent release into plasma under ad libitum feeding conditions and during short-term fasting. Cholecalciferol was administered for $14 \mathrm{~d}$ and the levels of cholecalciferol in plasma and adipose tissue and of $25(\mathrm{OH}) \mathrm{D}$ in plasma were monitored from day 0 up to day 101 . To promote adipose tissue mobilization, two subgroups of rats were fasted for $3 \mathrm{~d}$, immediately after cessation of cholecalciferol treatment and $84 \mathrm{~d}$ after discontinuation of treatment. Serum $\mathrm{Ca}$ and phosphate were monitored to detect biochemical signs of vitamin $\mathrm{D}$ toxicity.

\section{Materials and methods}

\section{Animals, vitamin $D$ and chemicals}

Female Wistar rats, weighing $150-180 \mathrm{~g}$, were obtained from Harlan (Zeist, The Netherlands). They were housed under standard laboratory conditions $(12 \mathrm{~h}$ dark $-12 \mathrm{~h}$ light,

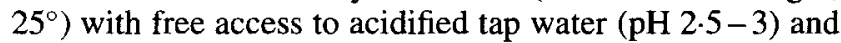
standard rodent chow, unless otherwise stated. The standard chow contained $37.5 \mu \mathrm{g}$ cholecalciferol $/ \mathrm{kg}$, corresponding to a daily background intake of about $0.75 \mu \mathrm{g}$ cholecalciferol from the diet. Cholecalciferol (cholecalciferol densitosum oleosum, $50 \mathrm{mg} / \mathrm{g}$ ) for administration was obtained from OPG (Utrecht, The Netherlands). For administration orally, it was diluted in arachid oil to $37.5 \mu \mathrm{g} / \mathrm{ml}$. Chemicals for the analysis of cholecalciferol by HPLC were obtained from Merck (Darmstadt, Germany) and Rathburn (Brunswig Chemie, Amsterdam, The Netherlands). Ergocalciferol and cholecalciferol standards for quantification were obtained from Sigma (St Louis, MO, USA).

\section{Experimental}

A group of 126 rats received orally $37.5 \mu \mathrm{g}$ cholecalciferol (dissolved in $1 \mathrm{ml}$ arachid oil) daily for $14 \mathrm{~d}$ (days $0-13$ ) at 22.00 hours. The last dose was administered 22.00 hours on day 13. Groups of six rats (a total of ninety rats) were killed at 10.00 hours under halothane anaesthesia on day 0 (i.e. before treatment), days $3,6,9$ and 12 (i.e. during treatment) and days $14,15,16,17,40,76,98,99,100$ and 101 (i.e. after treatment). The rats were weighed and samples of blood were drawn from the aorta both in the presence (to permit coagulation) and absence of EDTA. Serum and EDTA-treated plasma were prepared by centrifuging for $10 \mathrm{~min}$ at $1700 \mathrm{~g}$ and $4^{\circ}$. Samples of perirenal and subcutaneous adipose tissue (about 1-2 $\mathrm{g}$ each) were removed, weighed, and frozen in liquid $\mathrm{N}_{2}$. Serum $\mathrm{Ca}$ and phosphate were measured immediately. Samples were stored at $-20^{\circ}$ for the measurement of other variables.

The remaining thirty-six rats were used for the study of vitamin $\mathrm{D}$ mobilization under fasting conditions on days 15-17 (eighteen rats) and days 99-101 (eighteen rats). Eighteen rats were fasted from $12 \mathrm{~h}$ after the last dose of cholecalciferol (i.e. from 10.00 hours on day 14). They continued to have free access to tap water. Groups of six rats were subsequently killed at 10.00 hours on days 15,16 and 17 , corresponding with fasting for 24,48 and $72 \mathrm{~h}$ respectively. Body weight was determined, and samples of blood and adipose tissue were collected and processed as described previously. The same protocol was used for the study of vitamin D mobilization on days 99-101. Ad libitum-fed counterparts served as controls. They were killed at 10.00 hours on days $14,15,16$ and 17 , and days $98,99,100$ and 101.

\section{Analyses}

Serum $\mathrm{Ca}$ and phosphate concentrations were determined using an MEGA automated analyser (Merck, Darmstadt, Germany). Plasma free fatty acid concentrations were determined in samples collected on days $15-17$ and days 99-101, using an enzymic kit (Wako NEFA C kit; Wako Chemical, Neuss, Germany).

Plasma 25-hydroxyergocalciferol and 25-hydroxycholecalciferol were measured as $25(\mathrm{OH}) \mathrm{D}$ by using a competitive radio-binding assay with ${ }^{3} \mathrm{H}$-labelled 25 hydroxycholecalciferol and vitamin D-binding protein from human serum after solid-phase extraction. Between-series $\mathrm{CV}$ at 16, 62 and $101 \mathrm{nmol} / \mathrm{l}$ were 13, 12 and $13 \%$ respectively.

Plasma and adipose tissue cholecalciferol levels were determined using reversed-phase HPLC with u.v. detection, following saponification, organic solvent extraction and further prepurification with straight-phase HPLC, essentially according to Thompson et al. (1982). Ergocalciferol served as an internal standard. In short, the sample $(1.0 \mathrm{ml}$ plasma, $1 \mathrm{~g}$ adipose tissue) was saponified overnight in ethanolic $\mathrm{KOH}$ at $70^{\circ}$ and extracted with hexane. For adipose tissue samples, the hexane layer was washed consecutively with $\mathrm{KOH}(50 \mathrm{~g} / \mathrm{l})$ ethanol $(300 \mathrm{ml} / 1)$ in saline $(9 \mathrm{~g} \mathrm{NaCl} / \mathrm{l})$ and saline. After evaporation to dryness at room temperature under a stream of $\mathrm{N}_{2}$, the residue was dissolved in $1.5 \mathrm{ml}$ hexane, followed by cholesterol precipitation with methanolic digitonin. After centrifugation, the hexane layer was collected, evaporated to dryness (at room temperature under $\mathrm{N}_{2}$ ), and redissolved in the straight-phase HPLC eluent (hexane-isopropanol; 99.5:0.5, v/v). Isocratic elution of vitamin $\mathrm{D}$ was performed using a Waters M6000A pump (Waters, Milford, MA, USA) at a flow-rate of $1.5 \mathrm{ml} / \mathrm{min}$, using a Spheri-5 silica column $(220 \times 4.6 \mathrm{~mm}$; Brownlee Applied Biosystems, Foster City, CA, USA) and a Waters 486 tunable absorbance u.v. detector at $260 \mathrm{~nm}$. This system does not separate ergocalciferol and cholecalciferol. A cholecalciferol standard was used for the establishment of their retention time and their subsequent collection from sample extracts. The collected vitamin D fraction was evaporated to dryness (at room temperature under $\mathrm{N}_{2}$ ). The purified vitamin $\mathrm{D}$ extract was redissolved in the reversed-phase HPLC eluent (acetonitril - tetrahydrofuran - water; $94: 5: 1$, by vol). Separation and detection of ergocalciferol and cholecalciferol was performed using a Waters M6000A pump at a flow-rate of $1.0 \mathrm{ml} / \mathrm{min}$, using a Spheri5 RP18 column (Brownlee) and a Waters 486 tunable absorbance u.v. detector at $260 \mathrm{~nm}$. Plasma $(\mathrm{nmol} / \mathrm{l})$ and adipose tissue (nmol/g wet weight) cholecalciferol levels were calculated by comparing the peak area ratios of ergocalciferol and cholecalciferol with those of equimolar 
standards. The within-series precision for cholecalciferol in plasma was calculated by measurement of six samples of a human plasma pool on six different occasions. The overall mean plasma cholecalciferol concentration was $134 \mathrm{nmol} / 1$ and the mean within-series $\mathrm{CV}$ amounted to 3.4 (range 1.7$7.7) \%$. The between-series precision and recovery were established by analysing a rat plasma pool with and without enrichment with 130 nmol cholecalciferol/1 on four occasions. The mean endogenous cholecalciferol concentration amounted to $364 \mathrm{nmol} / 1(\mathrm{CV} 2.7 \%$ ) and the mean recovery was $93.6 \%$ (CV $11.6 \%$ ). The within-series precision of cholecalciferol in adipose tissue was measured by the 6fold analysis of hog lard. The CV was $28.1 \%$ at a mean cholecalciferol content of $32 \mathrm{pmol} / \mathrm{g}$. The within-series recoveries were measured by enrichment of lard with 78, 156, 234 and $312 \mathrm{pmol}$ cholecalciferol $/ \mathrm{g}$. The recoveries $(\% ; n 6)$ amounted to: $73.6(\mathrm{CV} 5.2 \%$ at $78 \mathrm{pmol} / \mathrm{g}), 92.5$ (CV $3.9 \%$ at $156 \mathrm{pmol} / \mathrm{g}), 94.6(\mathrm{CV} 3.0 \%$ at $234 \mathrm{pmol} / \mathrm{g}$ ) and $91.2(\mathrm{CV} 3.5 \%$ at $312 \mathrm{pmol} / \mathrm{g})$.

\section{Data analyses}

Body weight was calculated relative to the body weight on day 14 and day 98 (start of fast) for fasting and ad libitum- fed rats that were studied on days $15-17$ and days 99-101 respectively. Serum and adipose tissue half-lives were estimated using standard pharmacokinetic calculations, using a program developed by Dr H. Proost, Department of Pharmacy, University of Groningen. The calculations assumed 1st-order kinetics without lag-time, one compartment and a multiple dosage regimen. Differences between groups were analysed using Student's $t$ test (Stevens, 1980). ANOVA (Stevens, 1980) was used to determine steadystate conditions. $P<0.05$ was considered significant.

\section{Results}

Fig. 1 shows the mean plasma cholecalciferol and 25(OH)D concentrations, together with the subcutaneous and perirenal cholecalciferol levels before, during and after oral administration of cholecalciferol to rats. Cholecalciferol was given at 22.00 hours from day 0 to day 13 and samples were taken at 10.00 hours. Plasma cholecalciferol increased rapidly, to reach steady-state levels at day 3. After treatment, plasma cholecalciferol declined rapidly, with a calculated half-life of $1.4 \mathrm{~d}$. Levels at the end of the study (day 101, 31.3 (SD 1.5) nmol/1) were comparable with those on day $0(31.8(\mathrm{SD} \mathrm{2.3}) \mathrm{nmol} / \mathrm{l})$. Levels of $25(\mathrm{OH}) \mathrm{D}$ in
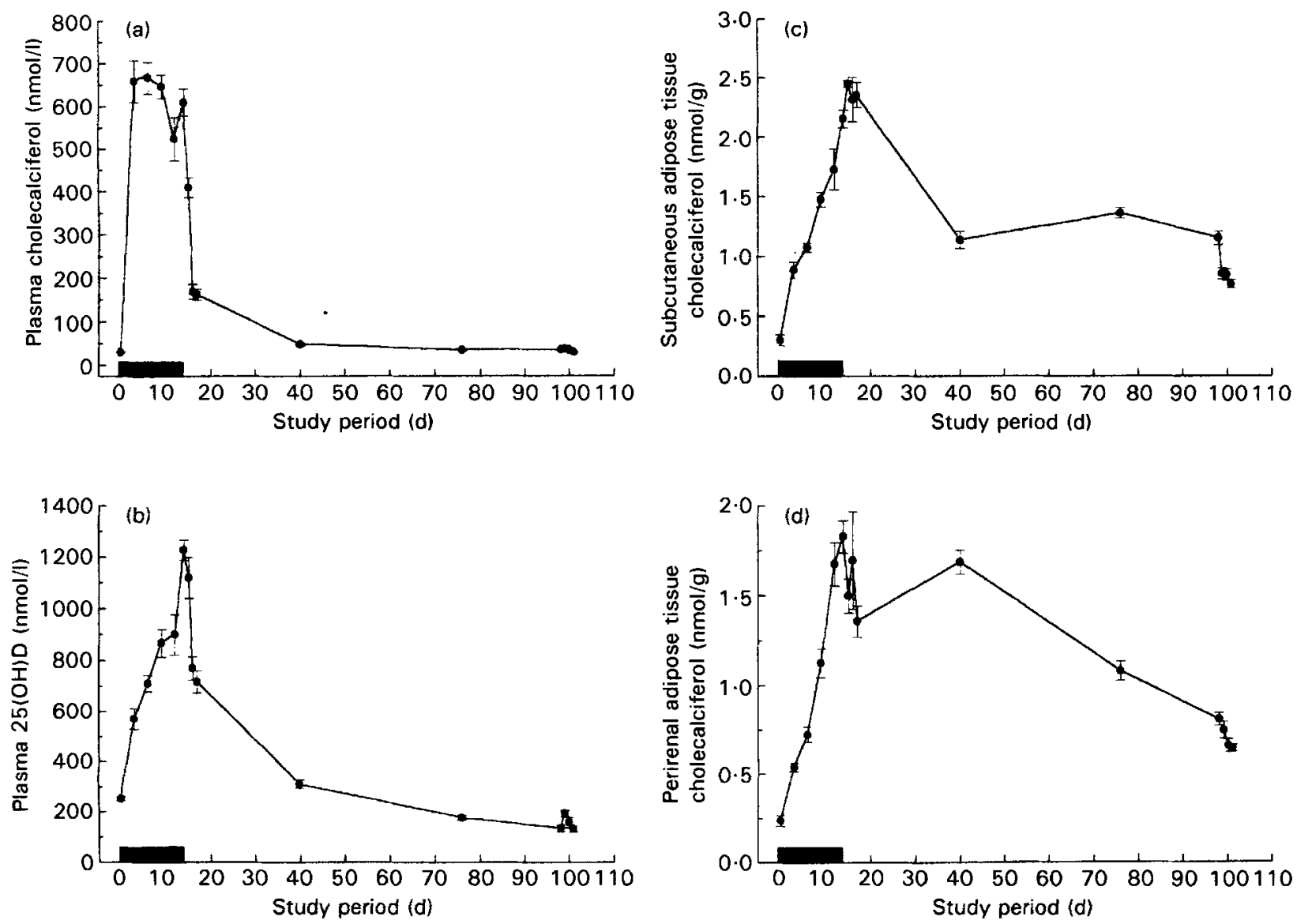

Fig. 1. Time-courses of plasma cholecalciferol (a) and 25-hydroxyvitamin $D(25(\mathrm{OH}) \mathrm{D}$; (b)) and subcutaneous (c) and perirenal (d) adipose tissue cholecalciferol contents in rats, before, during and after supplementation with $\mathbf{3 7 . 5} \mu \mathrm{g}$ cholecalciferol/d. Cholecalciferol was administered orally from day 0 to day 13 at 22.00 hours and samples were taken at 10.00 hours. ( ), Supplementation period. Data points represent means with their standard errors, represented by vertical bars, for groups of six rats. For details of procedures, see p. 528. 
plasma, and cholecalciferol in subcutaneous and perirenal adipose tissue increased linearly during treatment. They subsequently declined, with half-lives (d) of 22.5 (plasma 25(OH)D), 80.9 (subcutaneous adipose tissue), and 97.4 (perirenal adipose tissue). Plasma levels of 25(OH)D on day $101(132(\mathrm{SD} \mathrm{11}) \mathrm{nmol} / \mathrm{l})$ were below $(P<0.0001)$ those on day $0(225$ (SD 8) nmol/l). Subcutaneous and perirenal adipose tissue cholecalciferol contents at the end of the study $(0.77$ (SD 0.03) and $0.65($ SD 0.02$) \mathrm{nmol} / \mathrm{g}$ respectively) were above $(P<0.0001)$ those on day $0(0.30$ (SD 0.04) and $0.24(\mathrm{SD} \mathrm{0.03)} \mathrm{nmol} / \mathrm{g}$ respectively).

Serum $\mathrm{Ca}$ and phosphate concentrations increased from baseline (day 0) to the end of the treatment (day 14); levels were: Ca 2.51 (SD 0.15) v. $2.96(\mathrm{SD} 0.10) \mathrm{mmol} / 1(P=$ 0.0001 ); phosphate 2.10 (SD 0.32) v. 2.69 (SD 0.32) mmol/1 $(P=0.001)$. Serum phosphate reached baseline levels $3 \mathrm{~d}$ after treatment $(2.14$ (SD 0.23) mmol/l, day 17). Serum Ca was still elevated $3 \mathrm{~d}$ after treatment (2.68 (SD 0.07) $\mathrm{mmol} / 1, P=0.035$, day 17 ) and reached baseline levels by $26 \mathrm{~d}$ after treatment $(2.57$ (SD 0.04) $\mathrm{mmol} / \mathrm{l}$, day 40).

Fig. 2 shows plasma free fatty acid concentrations and the relative body weights of fasting and ad libitum-fed rats. Rats were fasted immediately after vitamin D treatment (days 14-17) and at about 3 months after its discontinuation (days 98-101). Fasting rats had higher free fatty acid concentrations than their ad libitum-fed counterparts. Compared with the controls, fasted rats had lower relative body weights from $1 \mathrm{~d}$ after initiation of fasting. After a $3 \mathrm{~d}$ fast, they has lost $15.6 \%$ (days 14-17) and $13.0 \%$ (days 98101) of their body weights; ad libitum-fed rats did not lose weight.

Fig. 3 shows the changes in plasma cholecalciferol and $25(\mathrm{OH}) \mathrm{D}$ concentrations, and in subcutaneous and perirenal adipose tissue cholecalciferol contents in fasting and ad libitum-fed rats. Plasma cholecalciferol and 25(OH)D concentrations of each of the groups decreased (ANOVA, $P<0.05$ ) from day 14 to day 17 and from day 98 to day 101. When compared with ad libitum-fed rats, fasting rats showed no difference in plasma cholecalciferol concentrations from day 14 to day 17 , but they had lower cholecalciferol concentrations from day 99 to day 101 . Plasma $25(\mathrm{OH}) \mathrm{D}$ levels of fasting rats were higher on days 16 and 17 , and on day 101 .

In fasted rats cholecalciferol contents $(\mathrm{nmol} / \mathrm{g}$ wet tissue) of subcutaneous and perirenal adipose tissues increased between day 14 and day 17, but not from day 98 to day 101. Compared with ad libitum-fed rats; fasting rats had higher subcutaneous adipose tissue contents on days 16 and 17, and on days 100 and 101. Fasted rats had higher perirenal adipose tissue contents on days 17 and 101 .

Neither fasting period caused differences in serum Ca and phosphate concentrations between fasting and $\mathrm{ad}$ libitum-fed rats.

\section{Discussion}

We monitored the levels of cholecalciferol in plasma and adipose tissue of rats that received $37.5 \mu \mathrm{g}$ cholecalciferol/d for $14 \mathrm{~d}$. This dose amounted to about fifty times their usual daily intake via the diet. The cumulative dose equalled their usual intake in $700 \mathrm{~d}$. After adminis-
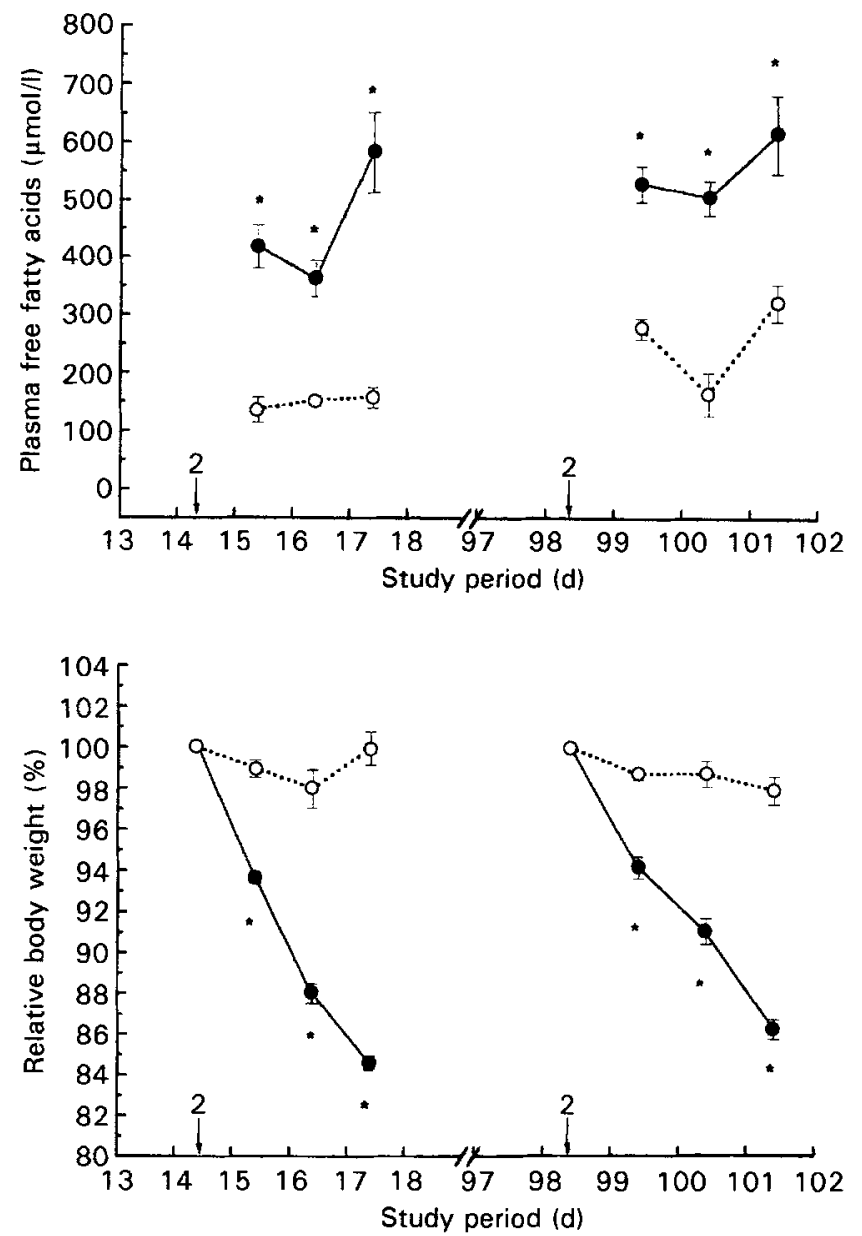

Fig. 2. Time-courses of plasma free fatty acid concentrations and relative body weight (body weight relative to that on days 14 and 98 ; $\%)$, in fasting (-0) and ad libitum-fed $(0 \ldots 0)$ rats. All rats had previously received orally $37.5 \mu \mathrm{g}$ cholecalciferol/d from day 0 to day 13 at 22.00 hours. Rats were weighed and samples were taken at 10.00 hours. Data points represent mean values with their standard errors represented by vertical bars for a group of six rats. $\downarrow$, The start of fasting ( 10.00 hours on days 14 and 98 ). Mean values for fasting rats were significantly different from those for ad libitum-fed rats: ${ }^{\star} P<0.05$. For details of procedures, see p. 528.

tration we monitored plasma and adipose tissue cholecalciferol under ad libitum feeding conditions for another $88 \mathrm{~d}$, and studied the effect of a $3 \mathrm{~d}$ fast in the period immediately after treatment and at the end of the study. We also measured plasma $25(\mathrm{OH}) \mathrm{D}$, since vitamin $\mathrm{D}$ is rapidly converted into $25(\mathrm{OH}) \mathrm{D}$ when it reaches the liver. Furthermore, $25(\mathrm{OH}) \mathrm{D}$ is generally considered to be a reliable index of functional vitamin $\mathrm{D}$ status because $25(\mathrm{OH}) \mathrm{D}$ has a long half-life and is the immediate precursor of 1,25-dihydroxyvitamin $\mathrm{D}$.

During treatment, plasma cholecalciferol showed a very rapid increase and a subsequent steady-state, whereas adipose tissue cholecalciferol and plasma $25(\mathrm{OH}) \mathrm{D}$ showed linear increases up to $1-2 \mathrm{~d}$ after discontinuation of cholecalciferol treatment (Fig. 1). The steadily increasing plasma $25(\mathrm{OH}) \mathrm{D}$, in the absence of any change of plasma cholecalciferol, seems of particular importance, since it is generally believed that vitamin $D$ toxicity is caused by the interaction of high concentrations $25(\mathrm{OH}) \mathrm{D}$ with the vitamin 

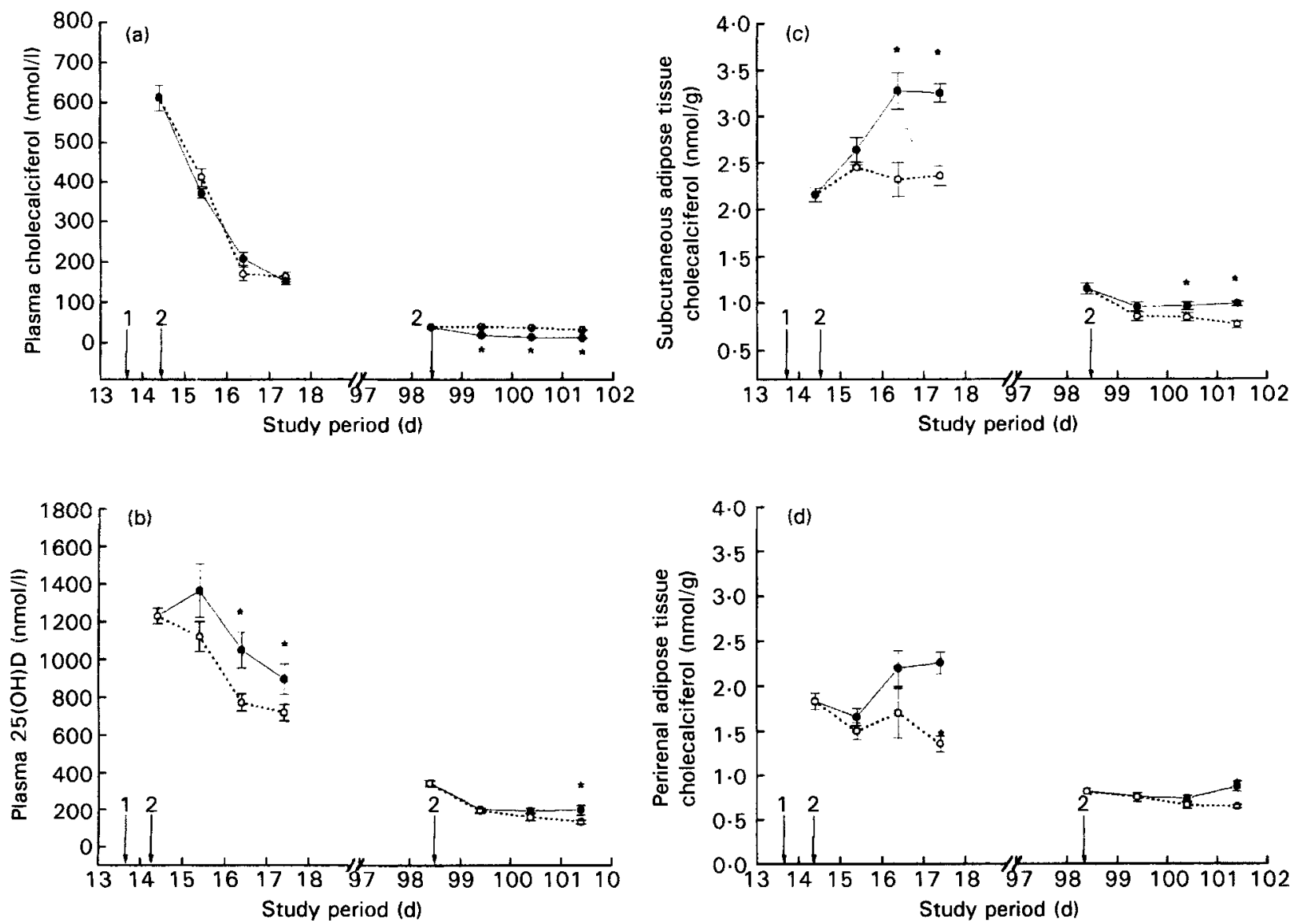

Fig. 3. Time-courses of plasma cholecalciferol (a) and 25-hydroxyvitamin $\mathrm{D}(25(\mathrm{OH}) \mathrm{D}$; (b)) concentrations and subcutaneous (c) and perirenal (d) adipose tissue cholcalciferol contents in fasting (--O) and ad libitum-fed $(0 \ldots \mathrm{O})$ rats. All rats had previously received $37.5 \mu \mathrm{g}$ cholecalciferol/ $\mathrm{d}$ from day 0 to day 13. Rats were weighed and samples were taken at 10.00 hours. Data points represent means with their standard errors represented by vertical bars, for a group of six rats. 1 , The last cholecalciferol administration (day $13,22.00$ hours) ${ }_{\downarrow}^{2}$, the start of fasting (10.00 hours at days 14 and 98 ). Mean values for fasting rats were significantly different from those for ad libitum-fed rats: ${ }^{\star} P<0.05$. For details of procedures, see p. 528.

D receptor. In agreement with this suggestion, we observed increases in serum $\mathrm{Ca}$ and inorganic phosphate during cholecalciferol treatment, while Ca levels at the end of the treatment (day 14;2.96 mmol/l) were close to those $(3.3 \mathrm{mmol} / \mathrm{l})$ reported for rats that received toxic vitamin D doses (three oral doses of $2.5 \mathrm{mg}$; Świerczyński et al. 1987).

The steady increase in $25(\mathrm{OH}) \mathrm{D}$ at $37.5 \mu \mathrm{g}$ cholecalciferol/d seems to contrast with the observations of Lips et al. (1988) and van der Klis et al. (1996) in human subjects. From their studies, it can be concluded that healthy adults who receive 10 or $20 \mu \mathrm{g}$ cholecalciferol/d show little or no difference in plasma $25(\mathrm{OH}) \mathrm{D}$ during 1 year of treatment, and that steady-state levels are reached in 1 week or less. The short-term conversion efficiency of orally-administered vitamin $\mathrm{D}$ to $25(\mathrm{OH}) \mathrm{D}$ may be dependent, therefore, on the vitamin D dose, and it is possible that above certain daily doses accumulation of $25(\mathrm{OH}) \mathrm{D}$ in plasma cannot be avoided. It is conceivable that the underlying mechanism of plasma $25(\mathrm{OH}) \mathrm{D}$ accumulation is increasing vitamin D uptake by the liver, as opposed to storage in adipose tissue, causing increasing exposure of vitamin D to the poorly regulated (Holick, 1994) hepatic 25-hydroxylase. A lower (physiological) vitamin D dose is likely, therefore, to exhibit different kinetics, and it also remains to be established whether present findings relating to a high dose can be extrapolated to human subjects. $\mathrm{Ca}$ and phosphate levels decreased rapidly after discontinuation of cholecalciferol administration (data not shown) concomitant with the decreases in plasma cholecalciferol and 25(OH)D (Fig. 1). Calculated half-lives of plasma cholecalciferol and $25(\mathrm{OH}) \mathrm{D}$ were in agreement with those reported for human subjects by Mawer et al. (1969, 1971; cholecalciferol 1d, 25(OH)D $15-30 \mathrm{~d})$. In contrast to plasma cholecalciferol and $25(\mathrm{OH}) \mathrm{D}$, adipose tissue cholecalciferol contents were still well above baseline levels at the end of the study. A similar pattern showing a gradual decrease after cessation of cholecalciferol administration was also reported by Rosenstreich (1971) and our calculated half-life was in agreement with their observation $(81 \mathrm{~d})$. It raised the question of whether adipose tissue vitamin $\mathrm{D}$ should be regarded as a slow-release pool that supports long-term functional vitamin $\mathrm{D}$ status (i.e. plasma $25(\mathrm{OH}) \mathrm{D}$ ), and whether massive vitamin $\mathrm{D}$ release from adipose tissue, e.g. during fasting, may cause an increase in plasma $25(\mathrm{OH}) \mathrm{D}$ and toxicity, as suggested by Connors et al. (1976).

Data in Fig. 1 show that the fifty times higher intake of cholecalciferol for $14 \mathrm{~d}$ was unable to increase plasma 
25(OH)D levels for longer than about $27 \mathrm{~d}$ after treatment, and that in this period only small changes occurred in adipose tissue cholecalciferol. Circulating 25(OH)D levels, therefore, seem particularly dependent on the continuous influx of vitamin D from the gastrointestinal tract, at least under the present condition of energy balance and level of vitamin $\mathrm{D}$ intake from the diet.

A different situation occurs, however, during negative energy balance and zero dietary vitamin $\mathrm{D}$ intake, as indicated by the study of fasting and ad libitum-fed rats. Fasting, in contrast to ad libitum feeding, was associated with high free fatty acid concentrations in plasma and continuing weight loss (Fig. 2). As a result, adipose tissue cholecalciferol content (nmol/g wet weight) increased, apparently because of the preferential loss of triacylglycerols from adipose tissue, as opposed to the loss of cholecalciferol (Fig. 3). Fasting and ad libitum-fed rats showed no differences in plasma cholecalciferol concentrations in the period immediately after cholecalciferol treatment, but $25(\mathrm{OH}) \mathrm{D}$ levels of fasting rats were clearly higher. This shows that, despite their zero intake of vitamin $\mathrm{D}$, fasting rats were able to increase their circulating $25(\mathrm{OH}) \mathrm{D}$ levels, most probably by vitamin $\mathrm{D}$ mobilization from adipose tissue. The zero dietary vitamin $\mathrm{D}$ intake by fasting rats was reflected in their lower plasma vitamin D levels during the fasting period at the end of the study. Also these rats developed higher plasma $25(\mathrm{OH}) \mathrm{D}$ concentrations, although the difference was obviously less pronounced.

We conclude that orally-administered cholecalciferol rapidly accumulates in adipose tissue and that it is only slowly released in periods of energy balance. Under these conditions circulating $25(\mathrm{OH}) \mathrm{D}$ levels may be dependent on dietary vitamin D intake and synthesis in skin. Fasting causes preferential loss of triacylglycerols (and possibly water) from adipose tissue, as opposed to vitamin D, but nevertheless augments plasma $25(\mathrm{OH}) \mathrm{D}$ levels under these conditions of zero dietary vitamin D intake. Toxicity because of massive vitamin $D$ release and subsequent $25(\mathrm{OH}) \mathrm{D}$ production does not take place. Adipose tissue is likely to act as a 'buffer to functional vitamin D status' by preventing unregulated production of $25(\mathrm{OH}) \mathrm{D}$ from dietary vitamin $\mathrm{D}$ up to a certain extent, and by slowly releasing vitamin D under ad libitum-fed and fasting conditions.

\section{Acknowledgements}

We thank Mr M. Volmer for his advice in statistical analysis. Dr J. Pratt is gratefully acknowledged for measuring plasma $25(\mathrm{OH}) \mathrm{D}$ concentrations. We thank $\mathrm{Dr}$ $\mathrm{H}$. Proost of the Department of Pharmacy (University of Groningen) for his advice regarding pharmacokinetic calculations.

\section{References}

Compston JE (1995) The role of vitamin D and calcium supplementation in the prevention of osteoporotic fractures in the eiderly. Clinical Endocrinology 43, 393-405.

Connors MH, Sheikholislam BM \& Irias JJ (1976) Vitamin D toxicity after dieting in hypoparathyroidism. Pediatrics 57, $794-797$.

Dawson-Hughes B, Dallal GE, Krall EA, Harris S, Sokoll LJ \& Falconer G (1991) Effect of vitamin D supplementation on wintertime and overall bone loss in healthy postmenopausal women. Annals of Internal Medicine 115, 505-512.

Fraser DR (1980) Vitamin D. In Vitamins in Medicine, pp. 42146 [BM Barker and DA Bender, editors]. London: W. Heinemann Medical Books Ltd.

Holick MF (1994) Vitamin D. In Modern Nutrition in Health and Disease, vol. 1, 8th ed., pp. 308-325 [ME Shils, JA Olson and M Shike, editors]. Philadelphia, PA: Lea \& Febiger.

Lips P, Wiersinga A, van Ginkel FC, Jongen MJM, Netelenbos JC, Hackeng WHL, Delmas PD \& van der Vijgh WJF (1988) The effect of vitamin D supplementation on vitamin D status and parathyroid function in elderly subjects. Journal of Clinical Endocrinology and Metabolism 67, 644-650.

Mawer EB, Backhouse J, Holman CA, Lumb GA \& Stanbury SW (1972) The distribution and storage of vitamin D and its metabolites in human tissues. Clinical Science 43, 413431.

Mawer EB, Lumb GA, Schaefer K \& Stanbury SW (1971) The metabolism of isotopically labelled vitamin $\mathrm{D}_{3}$ in man: the influence of the state of vitamin D nutrition. Clinical Science 40, 39-53.

Mawer EB, Lumb GA \& Stanbury SW (1969) Long biological half-life of vitamin $\mathrm{D}_{3}$ and its polar metabolites in human serum. Nature 222, 482-483.

Reichel H, Koeffler HP \& Normaan AW (1989) The role of the vitamin D endocrine system in health and disease. New England Journal of Medicine 320, 980-991.

Rosenstreich SJ, Rich C \& Volwiler W (1971) Deposition in and release of vitamin $D_{3}$ from body fat: evidence for a storage site in the rat. Journal of Clinical Investigation 50, 679-687.

Schwartzman MS \& Franck WA (1987) Vitamin D toxicity complicating the treatment of senile, postmenopausal, and glucocorticoid-induced osteoporosis. American Journal of Medicine 82, 224-230.

Stevens J (1980) Applied Multivariate Statistics for the Social Sciences. London: Lawrence Erlbaum Associates.

Świerczyński J, Nagel G \& Żydowo MM (1987) Calcium content in some organs of rats treated with a toxic calciol dosis. Pharmacology 34, 57-60.

The Committee on Nutrition of the Elderly, Food and Nutrition Council (1995) Advise Nutrition of the Elderly. The Hague: Nutrition Board.

Thompson JN, Hatina G, Maxwell WB \& Duval S (1982) High performance liquid chromatographic determination of vitamin $\mathrm{D}$ in fortified milks, margarine, and infant formulas. Journal of the Association of Official Analytical Chemists 65, 624-631.

van der Klis FRM, Jonxis JHP, van Doormaal JJ, Sikkens P, Saleh AEC \& Muskiet FAJ (1996) Changes in vitamin-D metabolites and parathyroid hormone in plasma following cholecalciferol administration to pre- and postmenopausal women in The Netherlands in early spring and to postmenopausal women in Curaçao. British Journal of Nutrition 75, 637-646. 